\title{
Analysis on Reform of the Relationship between Teaching and Learning of College English Teaching
}

\author{
Cui Yuexia \\ Office of Academic Affairs, Weifang University of Science and Technology, Weifang Shandong 262700
}

\begin{abstract}
There are substantial changes of the relationship between teaching and learning in college English teaching. On one hand, the dominant role of teachers has been changed. New teaching idea advocates the dominant role of students and also their active participation in teaching. On the other hand, the reform has combined teaching with learning which propels the interaction between them. Thus, based on the features of college English teaching, this paper, which aims to promote the quality of college English teaching and help cultivate professional and high-quality inter-disciplinary talents for our society, has analyzed the relationship between teaching and learning and came up with solutions to problems lurking in present college English teaching after specific reflection.
\end{abstract}

Keywords: college English; teaching reform; teaching and learning; problems; reflection.

\section{Introduction}

Owing to the leading role which America and Britain play in global economy, military affairs, culture and many other fields, and also the development of global economic integration, English, as the most widely used language in the world, has received more and more global attention and been used more and more widely. After reform and open, our country attaches great importance to learning of English. Some children even begin to learn English during preschool education. College students, who have learnt English for at least 9 years (we begin English teaching in grade three in primary school), not only have essential promotion in English learning, but also have difficulties in practice, such as communication and translation. These situations which reflected in English teaching, like dumb English and high scores and low abilities, are harmful to quality-oriented education. At present, in English teaching reform, we attach great importance on the analysis of relationship between teaching and learning in English teaching and promotion of English comprehensive abilities of college students.

2. Problems Lurking in Relationship between Teaching and Learning in College English Teaching

\subsection{Analysis of Relationship between Teaching and Learning}

As we all know, it is teachers' responsibilities to spread knowledge and help solve students' questions in learning. While, students not only just receive the instruction from teachers but also continuously explore and develop their self-consciousness and initiative of learning. In the process of learning, "teaching" of teachers' is important, but "learning" of students' has more effect on students' comprehensive qualities and practical abilities. Just as in the process of running, students can run faster by themselves than being pulled by teachers. The responsibilities of teachers are to tell students how to run and where to run. And then, students strive to develop in the direction of teacher's guidance depending on their self-consciousness, willpower and desire for knowledge. Under the interaction of teaching and learning, students effectively grasp the essence of English and flexibly put the knowledge they have learnt into practice to absorb it. It not only promotes students' comprehensive qualities and abilities, but also promotes the quality of talents in colleges.

\subsection{Problems Lurking in Relationship between Teaching and Learning in Modern College English Teaching}

College education is an important phase in English teaching which has significant meaning to promote students' English abilities. Along with the reform from exam-oriented education to quality-oriented education, reform in English teaching has reaped some fruits, but there are still some shortcomings. For teachers, firstly, with the reform in English teaching, college English teaching has high requirements for teachers. But at present, some college English teachers have weak awareness of competition. They neither try to expand the breadth of their knowledge, nor pay attention to the connection between teaching and modern technology. For instance, some teachers' inexperienced application of computers and the Internet has hindered the search and application of English teaching information on the Internet. Otherwise, teachers' inexperienced application 
of computers and the Internet also hinders the effect of communication platform between students and teachers which is built on the Internet. What's more, teachers' teaching ideas cannot keep up with the trend of the times which may lead to generation gap between teachers and students will have an influence on teaching quality. Secondly, some teachers hold the view that teaching is students' obedience and reception to teachers' instruction. The slow updating of teachers' teaching ideas will block students' dominant roles in the process of teaching. And it's hard to arouse students' initiative and enthusiasm for English learning, this situation leads to the low learning efficiency of students. In addition, under the influence of these teaching ideas, teachers are tired of teaching and students cannot learn profoundly and clearly, this situation really has a bad influence on reform in English teaching. Thirdly, teachers are deficient in innovation in English teaching. On one hand, some teachers biased think that traditional teaching methods are recognized and proved right by practice. Thus, they stick to original teaching methods and neglect the change and development of the era. This biased thought leads to teachers' narrow scope of knowledge. On the other hand, some teachers lack initiative for teaching and treat teaching as finishing tasks. Their inadequate preparation before classes has a bad influence on the spread of knowledge on classes. Some of them just repeat the contents in books and don't matter students' feelings. When the bell rings, they perform just like having finishing tasks and then wait for another class. They teach in the same method and language, and also ask same questions. These situations do have an effect on teaching quality.

For students, firstly, students learn passively. For instance, teachers need to call the roll to make sure that some of students will attend the class (they are afraid of failing the English exam for absence). Although they attend the class, they don't pay attention to what teachers say. Their absence of mind directly leads to low efficiency of learning. For another example, students don't actively involve in learning and memorizing what teachers have taught. They just recite knowledge which is related to exams. Thus, they learn nothing after they finish exams. The English knowledge which they have learnt is limited and they also cannot apply it into practice. This situation makes students win high scores in exams but have low abilities. Secondly, some students have biased ideas on English teaching. They think that effect of learning mostly depend on teachers' teaching and has nothing to do with themselves. They are particular with teachers but seldom consider that their enthusiasm for knowledge has great effect on the effect of learning. They are too dependent on teachers when they study and solve problems they are confronted to solve problems and study independently. Their weakness in practice does have an effect on promotion of students' English comprehensive qualities. Thirdly, students seldom communicate with teachers. Some students are too afraid of teachers to question teachers when they feel confused. They are weak in learning independently and lack creativity in English learning. Some students care less about teachers' guidance; they pay more attention to their own feelings. When teachers impart knowledge, they sleep in classes, listen to music, play games or chat on the Internet. In a word, they neither listen to teachers nor learn by themselves. Fourthly, students don't have a correct master of teaching methods in English learning. They think that learning English is a process of memorizing mechanically. They pay too much attention on the memory of words and the recitation of sentences, but neglect the creative application of English. This situation leads to the low efficiency of students' English learning.

\section{Analysis on Problems Lurking in Rela- tionship between Teaching and Learning in College English Teaching}

In a word, problems lurking in relationship between teaching and learning are majorly from two aspects-from teachers and from students. According to different subject, reasons which contribute to obstacle to English teaching are various.

\subsection{Analysis on Problems in Teachers' Teaching}

It is obvious that teachers play a role of teaching in teaching activities. There are four factors contributing to problems in teaching. Firstly, teachers don't have strong sense of responsibility for teaching. They don't pay much attention to promote themselves or enlarge their scope of knowledge. Teachers also excessively value their dominant role in teaching activities, blindly ask students to obey their guidance and neglect students' participation in teaching activities. Secondly, teachers' teaching ideas cannot keep up with the trend of the times. They cannot properly know their weakness in teaching and resist innovations in English teaching. They hold the view that they have taught for so many years, thus they definitely know how to teach. Their confidence in their teaching methods hinders the spread and practice of innovation ideas in English teaching reform. Thirdly, at present, teaching assessment mode in colleges is in a process of continuous developing and perfecting. Teaching evaluation mechanism which focuses on scores of exams has an effect on the innovation in English teaching reform. Teachers pay too much attention on scores of CET-4, CET-6 and many other English exams, but neglect the development of students' potential learning abilities and cultivation of students' abilities to put what they have learnt into practice. These situations lead to the shortage of English talents in colleges. What's more, teachers don't have a good understanding of English teaching reform and also excessively centralize their roles in teaching activities. For instance, sometimes, they neglect problems which are questioned by students and don't actively help them solve those problems. Or, they pay little attention to communication with students which may trigger gaps between students and themselves and have great effect on close corporation between students and teachers in teaching activities.

\subsection{Analysis on Problems in Students' Learning}

As we all know, students play a role of learning in teaching activities. There are four factors contributing to 
problems in learning. Firstly, students are too relaxed after they pass the college entrance examination. They pursuit a life state of freedom and relaxation and abandon their study. Some students are too satisfied with their scores in college entrance examination which have an effect on their study leads to their poor English grades in colleges. Some students are too pessimistic about their future after graduation. They think that there are too many college graduates and it's hard for them to find good jobs. This mental state has great influence on students' enthusiasm for English learning and students sometimes learn passively. Students learn passively and excessively depend on teachers' education and supervision which leads to their low efficiency and low ability in English learning severely effect promotion of students' comprehensive quality. Secondly, students don't have a good understanding of English teaching. On one hand, students have no interest in English and attribute their unsatisfactory performance in English classes to teachers. On the other hand, because of some teachers' teaching methods are boring and lack creativity, students have no enthusiasm for English classes. They may feel sleepy when they have English classes and lack self-consciousness in English learning. This situation which attaches students with great pressure contributes to the fact that students cannot make an improvement by working hard. Thirdly, students do not have enough communication with teachers. Affecting by traditional education ideas, students have a feeling of reverence and distance towards teachers. This attitude contributes to the lack of communication between teachers and students. Moreover, students' psychological factors, such as having no interested in study and being indifferent to teachers' attention, also contribute to the lack of communication between teachers and students. Fourthly, students do not have a good and full understanding of teachers' inspiration and guidance and they also pay little attention to explore and research on English. The lack of exploration spirit in English study and the rigid methods of English learning which mostly depend on reciting and dictating make students feel boring about English learning. These factors all have an influence on students' enthusiasm for English learning and contribute to obstacles for students to promote their English.

\section{Reflections on Relationship between Teaching and Learning in College English Teaching}

Teaching and learning have close connection with each other in college English teaching. In college English reform, firstly, we should well spread these innovation ideas to make sure that all the teachers and students have a good understanding of these ideas which may have a positive influence on English teaching reform. These ideas can also help properly build teachers and students' status in teaching activities. Secondly, innovation teaching ideas pay much attention to students' dominant role in teaching activities. On one hand, we should gradually cultivate students' enthusiasm and selfconsciousness for English learning and teachers pay more attention to guide and inspire students in teaching activities which can help students find proper learning methods through exploring and surveying by themselves. On the other hand, we should try to promote students' status and strengthen students' participation in teaching activities which can perfectly combine teaching with learning. Teachers and students reaching an agreement on English teaching not only make both sides work independently but also can help them achieve teaching goals by communication between both sides. What's more, attaching great importance on communication between teachers and students gives teaching and learning enough chance to work together and play greater role. On one side, teachers should try to make friends with students and spread knowledge in an amiable manner. At the same time, teachers should pay more attention to cultivating students' self-study ability and exploring students' potential to learn. Teachers active providing students with opportunities to perform in English classes can help students build enough confidence and sense of achievement which can help them take advantage of their ability of English learning and active participate in teachers' teaching activities. On the other side, students should abandon their biased ideas towards English learning and have a proper attitude towards scores and study in colleges. Students active participating in English teaching and communicating with teachers can help build a harmonious atmosphere for study. Teachers' correct guidance and caring are also important. What's more, teachers should actively promote teaching of freedom and democracy which can help develop students' individualities. Based on characteristics of college English teaching, we should treat students' self-development as premise. Communication between students and teachers can promote both the effect of English learning and English teaching. In a word, in a democratic and harmonious teaching atmosphere, we should pay the same attention to English teaching and learning and achieve success in English teaching reform to cultivate professional and skilled talents.

\section{Conclusion}

Even though English learning is an accumulation process, teaching methods have great influence on students' learning effect in the process of teaching. If teachers can grasp good teaching methods, college students can make a huge improvement in English learning. Teaching is important, but we cannot realize integral improvement of English teaching only through teachers' guidance. But without teachers' guidance, students can only learn aimless and can make no improvement in learning efficiency. Thus, we should pay attention to the combination of teaching and learning in college English teaching. We should have a proper understanding of the definition of teaching and learning and improve the effect of English teaching reform stably and continuously.

\section{References}

[1] Xing Lina, Liu Xiaoling, Zhao Haijun. Research on Cultivation of Teaching Staff in Colleges Based on College English Reform [J]. Journal of Hubei University of Economics (Column of Humanities and Social Sciences). 2011, 08(1): 202-203. 
[2] Wu Hongzhi. Teaching of Three Bases in the New Trend of College English Reform[J]. Journal of Agricultural Universities of Southwest (social sciences). 2009, 7(1): 159-163.

[3] Yang Xiaoqiong. Primary Exploration on Zero-Class-Hour of Advanced English Reading - Case Study of Students in A Class of College English Reform[J]. Journal of Yangtze Normal University. 2012(6): 104-107.

[4] Cai Jigang. Research on Foundations and Countermeasures of Post-College English Reform[J], Media in Foreign Language Instruction. 2010(3): 3-12
[5] Jiang Suqin, Krashen Theory of Second Language Acquisition and English Listening Teaching with Media Assistance -Empirical Study on Mode of College English Teaching Reform. Foreign Languages Research. 2010(3):140-143.

[6] Wei Yuehong, Analysis on the superficial effect of teachers' in College English Reform[J]. China Electric Power Education. 2009(17): 222-223.

[7] Zhang Zhengyong, Exploration on Dilemma and Solutions to Problems Facing in College English Reform in Ethnic Mountainous Area[J]. Overseas English(Volume One). 2012(12): 378-379. 